\title{
Energy recovery from anaerobic co-digestion with pig manure and spent mushroom compost in the Mekong Delta
}

\author{
Thu hồi năng lương tù quá trình ủ yếm khi kết hợp phân heo và rơm sau ủ nấm \\ ơ đồng bằng sông Củu Long
}

Research article

Nguyen, Vo Chau Ngan ${ }^{1,2} *$; Fricke, Klaus ${ }^{2}$

${ }^{I}$ College of Environment \& Natural Resources, Can Tho University, Vietnam; ${ }^{2}$ Leichtweiß-Institute for Hydraulic Engineering and Water Resources, Technical University of Braunschweig, Germany

\begin{abstract}
This study aimed at seeking for the solution to recover the energy from agriculture waste in the Mekong Delta, Vietnam. The spent mushroom compost - a residue from the mushroom growing was chosen for co-digestion with pig manure in anaerobic batch and semi-continuous experiments. The results showed that in case of spent mushroom compost made up $75 \%$ of the mixed substrate, the gained biogas volume was not significantly different compared to the treatment fed solely with $100 \%$ pig manure. The average produced biogas was $4.1 \mathrm{~L} \times \mathrm{day}^{-1}$ in the experimental conditions. The semi-continuous experiments remained in good operation up to the $90^{\text {th }}$ day of the fermentation without any special agitating method application. The methane contents in both experiments were around $60 \%$, which was significantly suitable for energy purposes. These results confirm that spent mushroom compost is possibly an acceptable material for energy recovery in the anaerobic fermentation process.
\end{abstract}

Nghiên cưu này nhằm tìm kiếm giải pháp thu hồi năng lượng tù̀ chất thải nông nghiệp tại ĐBSCL, Việt Nam. Rơm sau ủ nấm - phế phẩm sau khi trồng nấm rơm - được chọn để ủ kết hợp với phân heo trong các bộ ủ yếm khí theo mẻ và bán liên tục. Kết quả cho thấy nếu phối trộn đến $75 \%$ rơm sau ủ nấm trong nguyên liệu ủ, tổng lượng khi thu được không khác biệt đáng kể so với thi nghiệm ủ 100\% phân heo. Trong điều kiện thí nghiệm, luợng khi thu được trung bình là 4.1 L.ngày ${ }^{-1}$. Thi nghiệm ủ bán liên tục vẫn vận hành tốt ở ngày thư 90 mặc dù mẻ ủ không được khuấy đảo. Hàm lương khi mê-tan đo được chiếm khoảng $60 \%$ hoàn toàn có thể sủ dụng cho các nhu cầu về năng lương. Nhũng kết quả thí nghiệm khẳng định có thể sử dụng rơm sau ủ nấm để thu hồi năng luợng thông qua quá trình ủ yếm khi kết hợp.

Keywords: anaerobic co-digestion, batch treatment, semi-continuous treatment, spent mushroom compost

\section{Background}

\subsection{Introduction}

Up to date, the biogas plant is strongly confirmed not only as a safe treatment place for livestock waste but also as gas supply source for household cooking, lighting, etc. The output residues from biogas plant can be used as organic fertilizer for gardening or to feed fish in a VACB farming system. In spite of the above-mentioned benefits of biogas plants, few farmers in the Mekong Delta (MD) can enjoy the full benefits of biogas plants for a long period. In the $\mathrm{MD}$, farmers normally raise pigs at smallscale so that in case the market price of pigs is low or the cost of livestock fodder is high, or pig diseases happen, they usually tend to decrease the number of pig herds or even to discontinue raising pigs until the favourable conditions are available. In that case, their biogas digesters just process discontinuously due to lack of pig manure (PM). The instability of PM supply seems to make the investment in installation of biogas digesters wasted. This is one of primary limits to the promotion of widespread application of biogas digesters in the MD, weakening the potentials of favourable conditions of the MD for biogas application and having an impact on environmental pollu- 
tion prevention in the area. To encourage the use of biogas digesters in the MD, this research aimed to find out additional local input materials potentially relevant to biogas digesters, particularly in case of PM in short supply.

Spent mushroom compost (SMC) is common in the MD due to the fact that it is residue from mushroom cultivation at household scale. Up to now, Vietnam has recently become the world's third largest exporter of mushroom with over one million tons of fresh mushroom produced in 2010 (iLumtics, 2008). Every ton of mushrooms results in one to two tons of dry spent residual materials (Rinker, 2002). It is also worth noting that there is very limited application of SMC for other uses, only small proportion of the SMC is used to cover soil to maintain the soil humidity for vegetable planting in the area. SMC itself as a waste could be a potential threat to the local environment. SMC were therefore chosen in the study due to their potential to biogas production and high availability with the expectation to promote the widespread development of biogas plants and to recommend a possible solution to the problem of SMC in the rural MD.

\subsection{Research objectives}

The objectives of the study are to test the hypothesis in the context of the MD and to explore the optimal mixing ratios of co-digestion $\mathrm{SMC}+\mathrm{PM}$ in biogas plants appropriate to the local conditions in MD. The result of this study is expected to contribute locality-based evidence supporting the encouragement of the local owners of biogas digesters to take into account the usage of SMC as potentially additional input materials for their biogas digesters, especially when the animal manure is in short supply.

The experiments are expected to give answers to the questions of:

- The influence of differential mixing ratios of SMC with $\mathrm{PM}$ on gas production by batch digester;

- The stability of the semi-continuous anaerobic codigestion of SMC to PM.

\section{Research methodology}

\subsection{Equipment preparation}

There were 18 sets of airtight digestion apparatus installed of which 15 digesters for batch fermentation and 3 digesters for semi-continuous fermentation. Each was composed of a $20 \mathrm{~L}$ plastic bottle connected to a gas collection pipe. All bonds from the digester body (the inlet, outlet, and gas pipe) were connected by soft joints for airtight and watertight. To minimize the development of algae population that creates oxygen inside the digesters, all bottles were covered by black nylon bags throughout the testing period. A $15 \mathrm{~L}$ aluminium bag connected directly to each of the digesters through its gas collection pipe in order to collect gas samples. There were two airvalves installed to the pipes in connection with the digest- er and the gasbag so as to switch the gas off when the gas was being recorded.
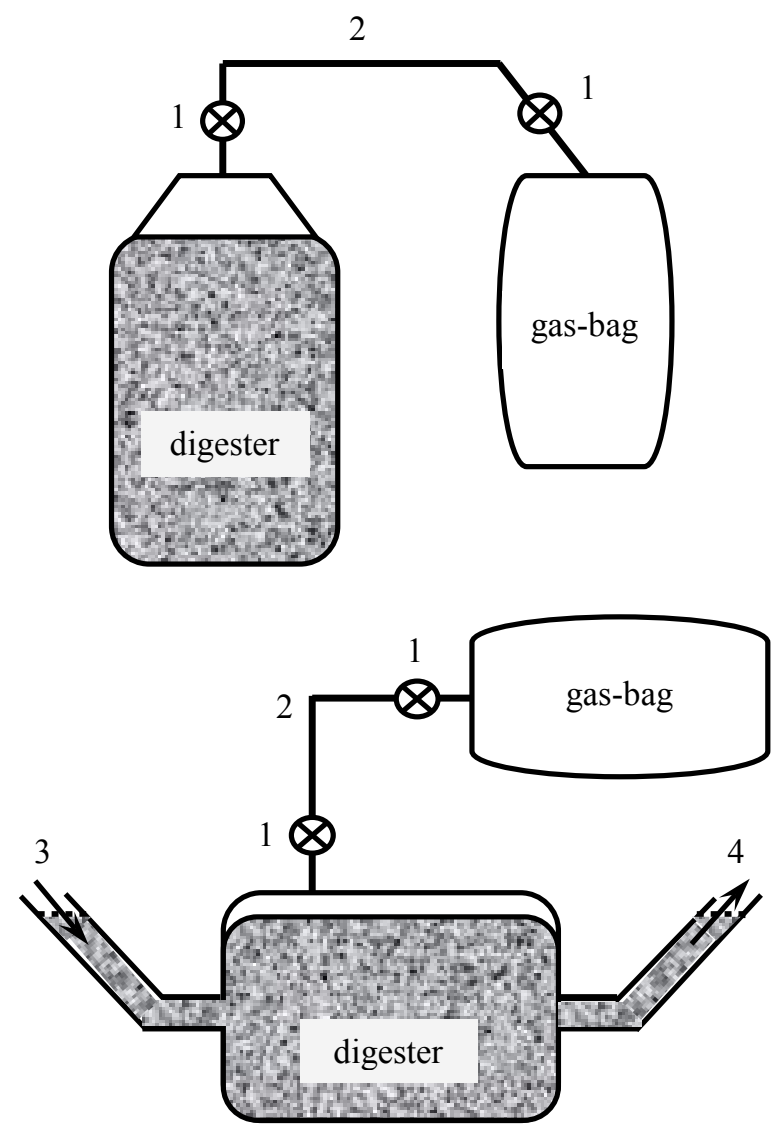

Figure 1. Treatment on batch experiment (above) and semi-continuous experiment (below)

(1) air-valve; (2) gas pipe; (3) inlet; (4) outlet

\subsection{Material preparation}

The input materials loaded for the anaerobic process were prepared as follows:

- PM collected from piggeries at Hoa An Center (located $40 \mathrm{~km}$ south of Can Tho city) was air-dried out at ambient temperature (about $25 \pm 4^{\circ} \mathrm{C}$ ) for one week before coming into use, and then the dried PM was manually mashed and mixed up until it became a homogenous form.

- SMC was collected from the farmers' households producing straw mushroom around Hoa An Center. The SMC were manually cut into approximate $1.0 \div 2.0 \mathrm{~cm}$ long pieces. The chopped SMC was air-dried at ambient temperature up to unchanged weight, and then it was manually mixed up until becoming a homogeneous form.

- Inoculums: to shorten the time of gas production, the seeding material which is the effluent taken from an existing active biogas plant was used. This is a 100 $\mathrm{m}^{3}$ biogas plant currently applied to treat the wastewater from the piggeries at Hoa An Center. 


\subsection{Analysis methods}

The ratio of $\mathrm{PM}$ to SMC in the mixture was defined based on their organic dry matter (ODM) value. So that the substrates before and after the experiments were taken and analysed for $\mathrm{pH}$, carbon (C), total Kjeldahl nitrogen (TKN), dry matter (DM), organic dry matter (ODM) and alkalinity according to the procedures in the Standard Methods for the Examination of Water and Wastewater which guideline by APHA (1995).

The gas measurements were taken after two-days operation of the batch treatments and after one-week operation of the semi-continuous treatments. The gas production was recorded daily with Ritter gas-meter (with the smallest scale of $20 \mathrm{~mL}$ ) and the biogas components were monitored weekly by a GA94 gas analyser. The gas record was expressed at ambient temperature and at stable atmosphere pressure $(1004 \div 1006$ mbar).

All of the experiments and the physical - chemical analysis were conducted at the Environmental Engineering Laboratory of the College of Environment and Natural Resources of Can Tho University in Vietnam.

\subsection{Experimental set-up}

\subsubsection{Batch treatments}

As regards anaerobic processes, the degradation of organic matters was measured based on ODM value of input material. Eder and Schulz (2007) suggested that the optimal input should be $1 \div 4 \mathrm{~kg}$ ODM day ${ }^{-1} \times \mathrm{m}^{-3}$ for an anaerobic digester. Based on this suggestion, the mixing ratio of input discharge in the experiments was chosen to be $1.25 \mathrm{~g} \mathrm{ODM} \mathrm{day}^{-1} \times \mathrm{L}^{-1}$. Consequently, $665 \mathrm{~g}$ (based on ODM values) was fed to the PM+SMC batch treatments.

For the batch treatments, $17.5 \mathrm{~L}$ inoculums were mixed together with $665 \mathrm{~g}$ mixture of PM and SMC. Both dried $\mathrm{PM}$ and SMC were directly loaded into the digesters without pre-treatment. Five co-digestion batches of PM and SMC were set to evaluate the influence of various mixing ratios on gas production. Each of the treatments was in triplicate.

$$
\begin{aligned}
& \text { SMC0: } 100 \% \mathrm{PM}+0 \% \mathrm{SMC} \\
& \text { SMC1: } 75 \% \mathrm{PM}+25 \% \mathrm{SMC} \\
& \text { SMC2: } 50 \% \mathrm{PM}+50 \% \mathrm{SMC} \\
& \text { SMC3: } 25 \% \mathrm{PM}+75 \% \mathrm{SMC} \\
& \text { SMC4: } 0 \% \mathrm{PM}+100 \% \mathrm{SMC}
\end{aligned}
$$

In the MD the normal retention time of the substrate in the biogas plant is 20 days. In this study, all of batch treatments were fermented in 28 days to check for the fermentation status of input materials. All treatments were mixed up by shaking the digesters manually once a day so as to increase the gas production.

\subsubsection{Semi-continuous treatments}

A semi-continuous experiment of $75 \% \mathrm{PM}+25 \% \mathrm{SMC}$ was set up in triplicate treatments. There were $17.5 \mathrm{~L}$ inoculums and $23.75 \mathrm{~g}$ ODM mixture of PM and SMC added as starting materials. From the $2^{\text {nd }}$ day, the daily feeding rate included $875 \mathrm{~mL}$ inoculums and $17.81 \mathrm{~g}$ ODM of PM plus $5.94 \mathrm{~g}$ ODM of SMC. The digesters were fed daily at the same time-point. In these treatments, only the action of feeding the digesters helped stir the substrate inside the digesters. These treatments were conducted for a period of 90 consecutive days.

\section{Results and discussions}

\subsection{Batch treatments}

\subsubsection{Biogas volume}

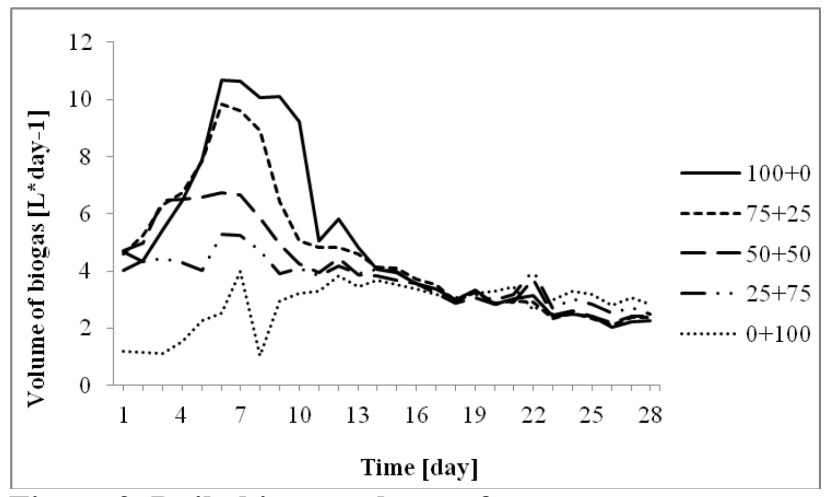

Figure 2. Daily biogas volume of treatments

The result of the daily generation of biogas with a variety of mixing ratios of $\mathrm{PM}+\mathrm{SMC}$ treatments is presented in Figure 2. The results showed that the biogas volume of the treatments reached maximum values around at the end of the $1^{\text {st }}$ week (treatment $0+100$ on the $7^{\text {th }}$ day and the others on the $6^{\text {th }}$ day). In the $2^{\text {nd }}$ week, the peak value of biogas volume fell down and then slightly declined until the end of the testing period. Up to the $4^{\text {th }}$ week, the produced biogas only accounted for $12.2 \%, 13.2 \%, 15.9 \%$, $19.4 \%$ and $26.3 \%$ of the total biogas volume in the treatments of $100 \% \mathrm{PM}+0 \% \mathrm{SMC}$, of $75 \% \mathrm{PM}+25 \% \mathrm{SMC}$, of $50 \% \mathrm{PM}+50 \% \mathrm{SMC}$, of $25 \% \mathrm{PM}+75 \% \mathrm{SMC}$, and of $0 \% \mathrm{PM}$ $+100 \% \mathrm{SMC}$, respectively. These results showed that four-week operation is insufficiently long to ferment the substrate contained in SMC.

The higher biogas production recorded in the last experimental period of the treatments with higher SMC content was possibly caused by high lignin content remaining in SMC. The study on methane production from rice straw by Lei et al. (2010) showed that the first peak of gas production happened after $20 \div 30$ days of operation, and the second peak presented after $60 \div 80$ days, but the second peak were always greater than the first peak. Because the fermentation time in this study lasted only 28 days, only PM and part of SMC were decomposed. As a result, only the first peak of gas production occurred in this study. 


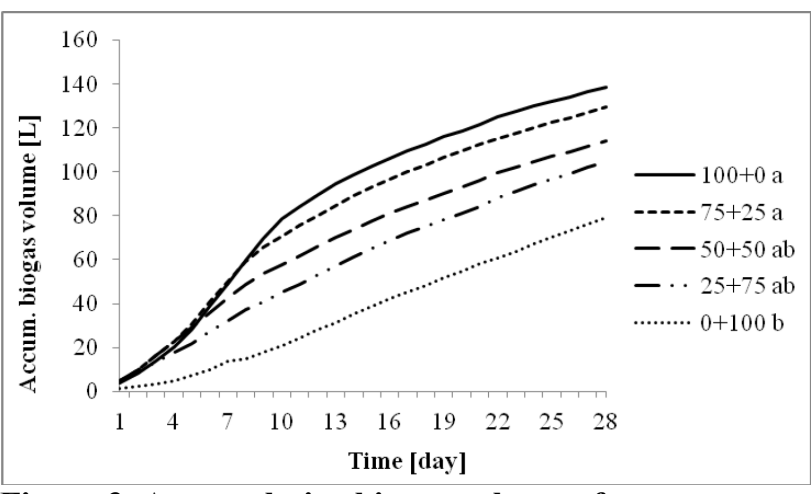

Figure 3. Accumulative biogas volume of treatments

In respect of the various mixtures of SMC and PM in the substrate, the treatments with a larger percentage of SMC in the mixture generated lower biogas volume. However, the generated biogas between the treatments with SMC and the control treatment was not significantly different (except the treatment with $0 \% \mathrm{PM}+100 \% \mathrm{SMC}$ ). The letters $a$ and $b$ in Figure 3 showed the difference in the total gas produced in the $\mathrm{PM}+\mathrm{SMC}$ treatments. The results showed that SMC could be applied as co-digestion with $\mathrm{PM}$ up to the mixing ratio of $25 \% \mathrm{PM}+75 \% \mathrm{SMC}$ without affecting the biogas production. In this connection, Mehta et al. (1990) reported that the biogas production from the SMC mixed with cow dung produced more biogas compared to the one without the mixture of cow dung.

The variation on gas production between the treatments was caused by the difference in $\mathrm{pH}$ and alkalinity values resulted by the various mixing ratios of PM and SMC. Among undigested substrates, PM alone is the most acidic while raw SMC is the most alkaline. In this study, after the experiment, the SMC substrate was the most acidic while the PM substrate was the most alkaline. It was observed that the SMC was high lignin content that exhibited a multi-stage gas production pattern. In fact, after the peak gas production in the $\mathrm{PM}+\mathrm{SMC}$ treatments, there were other small "peak" values (on the $12^{\text {th }}, 22^{\text {nd }}$ and $27^{\text {th }}$ day). It is believed that there would be re-fermentation cycle occurring in anaerobic digestion in order to complete the gasification of SMC.

Before the fermentation, the alkalinity value of the treatments decreased due to higher percentage of SMC in the mixture. The alkalinity is the result of the release of amino groups $\left(-\mathrm{NH}_{2}\right)$ and production of ammonia $\left(\mathrm{NH}_{3}\right)$ as the proteinaceous wastes are degraded (Gerardi, 2003). By that fact, the treatments with high percentage of SMC could not remain the optimum alkalinity. After the experiment, the alkalinity of the treatments tended to increase more than that of the input substrate (except the treatment of $100 \% \mathrm{PM}+0 \% \mathrm{SMC}$ ). The alkalinity variation was the greatest in the treatment of $0 \% \mathrm{PM}+100 \% \mathrm{SMC}$. The output alkalinity from the treatments with SMC content was volatile but this tendency was incomprehensible.
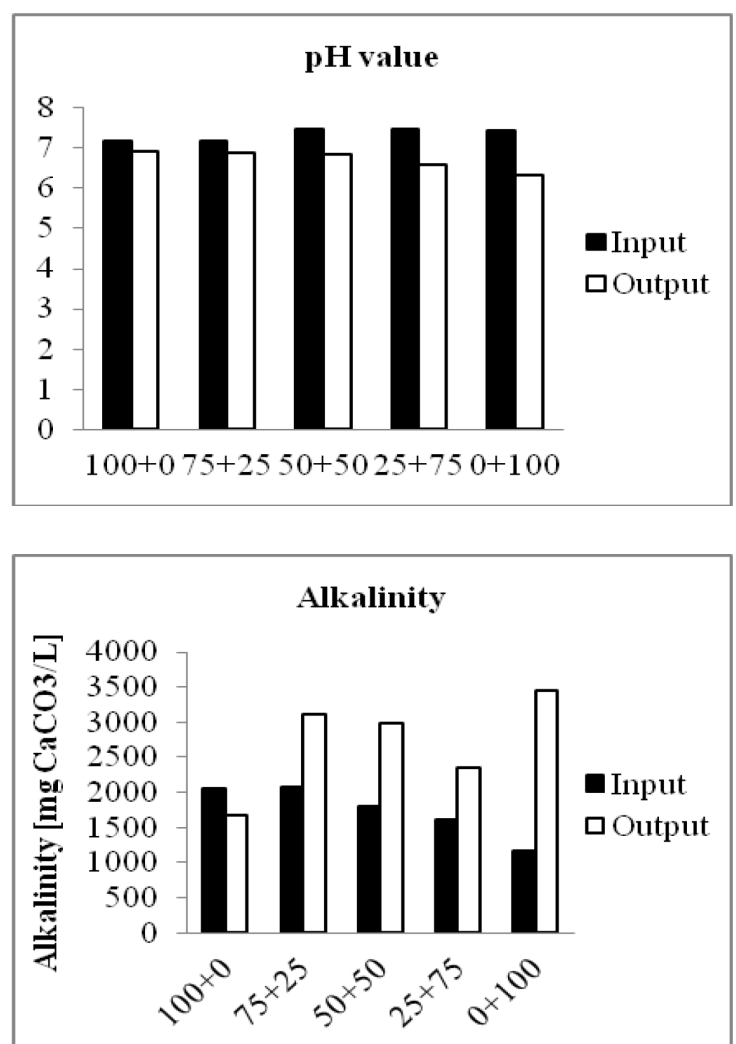

Figure 4. Control parameters of treatments

\subsubsection{Biogas composition and the specific biogas yield}

Figure 5 shows the biogas composition obtained when the different mixtures of PM and SMC were used as substrates. The methane contents were not much different by the mixing ratios of PM and SMC in the treatments (48.6 $\div 55.7 \%$ ), but there was a slight decrease in the percentage of methane in the treatments with the smaller percentage of SMC compared to the treatments with the larger percentage of SMC.

In all the treatments, the methane content increased gradually. The maximum percentage of methane in the treatments was found in the $4^{\text {th }}$ week. In this connection, Lei et al. (2010) reported that the methane content from rice straw anaerobic digestion could be greater than $50 \%$ after $18 \div 23$ operation days, and these values remained between $60 \div 80 \%$ from the $30^{\text {th }}$ day onward.

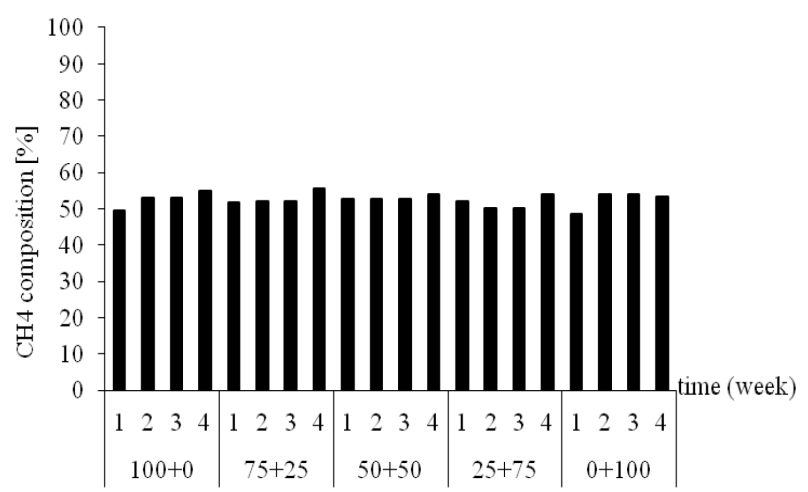

Figure 5. $\mathrm{CH}_{4}$ content in batch treatments

Calculation on biogas yield for each treatment was based on weekly biogas production and fermented ODM value. The results showed that higher biogas yield was present in the treatments with lower percentage of SMC in the mix- 
ture ratio. Compared to the control treatment, the biogas yield of the treatments of $75 \% \mathrm{PM}+25 \% \mathrm{SMC}$, of $50 \% \mathrm{PM}+50 \% \mathrm{SMC}$, of $25 \% \mathrm{PM}+75 \% \mathrm{SMC}$ and of $0 \% \mathrm{PM}$ $+100 \%$ SMC only got $84 \%, 76 \%, 69 \%$, and $53 \%$, respectively.

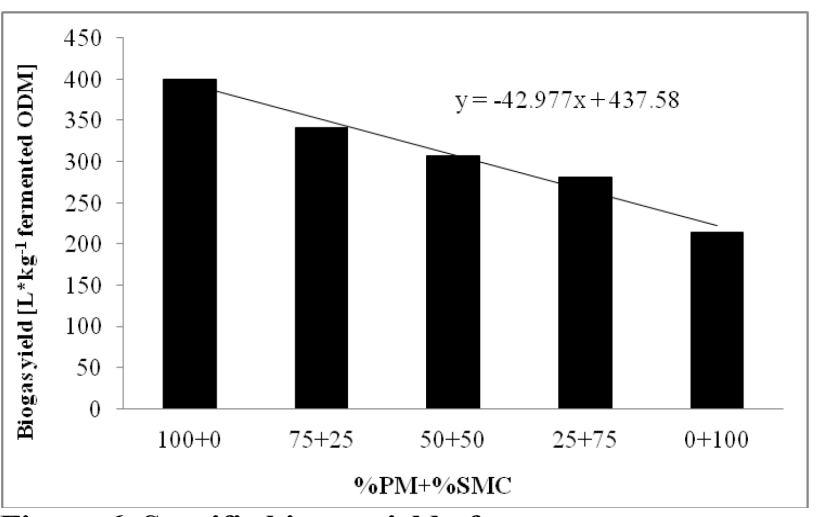

Figure 6. Specific biogas yield of treatments

In addition, the relationship between the biogas yield and the percentage of SMC inside the co-digestion showed a linear curve fit represented by equation (1) with a goodness of fit equal to 0.978 .

$$
y=-42.977 x+437.58
$$

where $\mathrm{x}$ : percentage of SMC in mixing substrate

$$
\text { y: biogas yield (L/kg fermented ODM) }
$$

By this linear equation, it is estimated that when replacing $25 \%$ of $\mathrm{PM}$ by $25 \%$ of SMC in the co-input material, the average biogas production decreased about $43 \mathrm{~L}$ per $\mathrm{kg}$ fermented ODM of the input material.

\subsection{Results of semi-continuous treatments}

\subsubsection{Biogas volume}

For the semi-continuous treatments, because little gas was generated in the first week of the experiment, gas recording in the first week was skipped but only started to record the gas production from the $8^{\text {th }}$ day up to the $90^{\text {th }}$ day. The daily gas productions from treatments were volatile and reached $2.0 \div 6.1 \mathrm{~L}$.

The biogas production followed a sharp increase in the first week and reached a stable range $\left(4 \div 5 \mathrm{~L}^{- \text {day }^{-1}}\right)$ in the second week. However, from the $57^{\text {th }}$ day onwards the gas production decreased and reached an average value of 3.2 L.day ${ }^{-1}$ up to the ending experimental period. The decrease in gas production at the later phase could be explained by the presence of un-degradable materials in the substrates. After feeding, some materials floated to the surface of the substrates. The floating materials gradually resulted in scum that prevented gas release from the substrate onto the upper part of digester. For a while, some pieces from the scum were fermented and combined with new feeding, thereby causing peak values at the later phase.

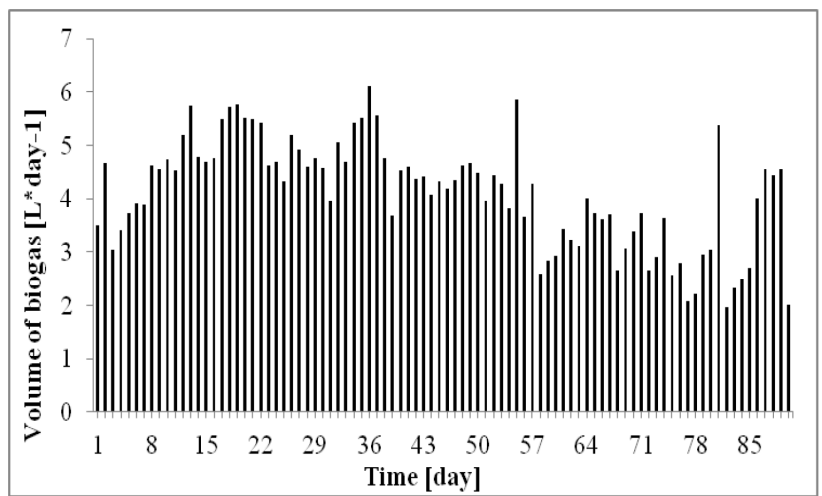

Figure 7. Daily biogas production of semi-continuous treatments

\subsection{2 $\mathrm{pH}$ and alkalinity}

The $\mathrm{pH}$ and alkalinity values of these treatments were recorded for the first 7 weeks. The $\mathrm{pH}$ ranged from $6.5 \div$ 7.5 which is not much different from the optimum range $6.6 \div 7.6$. By time, the $\mathrm{pH}$ values in the treatments tended to decrease gradually.

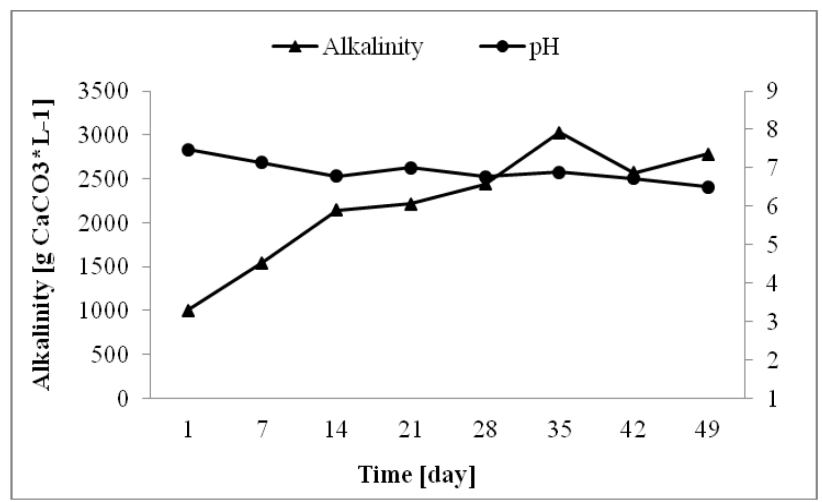

Figure 8. Control parameters of the treatments

The drop of $\mathrm{pH}$ and methane content signifies hydraulic overload, organic overload or insufficient buffering capacity in digesters. In this study, the $\mathrm{pH}$ and methane content tended to decrease in the first 7 weeks but the alkalinity remained in stable range. It could be inadequate anaerobic microorganism in the substrate causing low $\mathrm{pH}$ and methane content.

The methane contents are to be expected to vary depending on feedstock. The average methane content in the biogas was $60.5 \%$ (in range of $57.5 \div 63.6 \%$ ), which was favourable for energy use purposes. Compared to the batch experiments, the methane content in the semicontinuous experiments seems to be higher and stable. In fact, by daily feeding, the semi-continuous treatments supplied more nutrients to microorganism that helped maintain their methanogenic activities. 


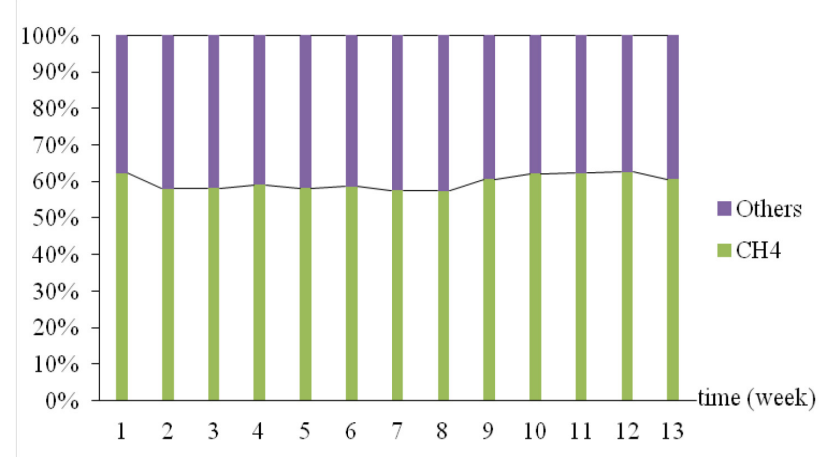

Figure 9. Biogas compositions of semi-continuous treatments

\section{Conclusions}

In this study, the anaerobic co-digestions of $\mathrm{PM}+\mathrm{SMC}$ were implemented in both of batch and semi-continuous experiments to test for energy recovery. The findings were recorded as follows:

- By mixing PM and SMC in the batch treatments, the higher percentage of SMC in the mixture ratio led to the lower biogas yield in the treatments. However, in case of SMC making up $75 \%$ of the mixed substrate, the gained biogas volume was not significantly different compared to the treatment fed solely with $100 \% \mathrm{PM}$. The average produced biogas was $4.1 \mathrm{~L}^{-\mathrm{day}^{-1}}$ in the experimental conditions. The produced biogas had good quality due to the average methane content in the biogas over $60 \%$ in the treatments, which is significantly suitable for energy purposes.

- The semi-continuous experiment remained in good operation up to the $90^{\text {th }}$ day of the fermentation without any special agitating method application. The experiments proved that in case of co-digestion of $\mathrm{PM}+\mathrm{SMC}$ with up to $25 \%$ biomass, the digester could operate very well for at least 3 months without any application of agitating method.

It can evidently be concluded that SMC can provide a viable constituent of a co-digestion feedstock for energy recovery in the MD. By co-digestion of SMC and PM, the bio-digester not only reuse the agricultural waste of SMC to generate more income but also protect the living environment by minimize the SMC discharge. Moreover, the biogas generation of the co-digestion as analysed in this study is significantly good enough to provide farmers with energy for cooking, lighting, etc.

\section{References}

[1] APHA - American Public Health Association 1995. Standard methods for the examination of water and wastewater (19 ed.). Washington DC, USA: American Public Health Association, American Water Works Association, and Water Pollution Control Federation.

[2] Eder, B., \& Schulz, H. 2007. Biogas-Praxis: Grundlagen, Planung, Anlagenbau, Beispiele, Wirtschaftlichkeit: Ökobuch Magnum.

[3] Gerardi, M.H. 2003. The microbiology of anaerobic digesters. United States of America: A John Wiley \& Sons, Inc.

[4] iLumtics. 2008. Báo cáo tóm tắt Ngành hàng nấm ở tỉnh Quảng Bình (The mushroom sector in Quang Binh province - A summarize report) (pp. 8). Quang Binh, Viet Nam: The Sustainable Management of Natural Resources in Central Vietnam.

[5] Lei, Z., Chen, J., Zhang, Z., Sugiura, N. 2010. Methane production from rice straw with acclimated anaerobic sludge: Effect of phosphate supplementation. Bioresource Technology, 101(12): 4343-4348. DOI: $10.1016 /$ j.biortech.2010.01.08

[6] Mehta, V., Gupta, J.K., Kaushal, S.C. 1990. Cultivation of Pleurotus florida mushroom on rice straw and biogas production from the spent straw. World Journal of Microbiology and Biotechnology, 6(4): 36-370. DOI: 10.1007/BF01202116

[7] Rinker, D.L. 2002. Handling and using "spent" mushroom substrate around the world. Paper presented at the $4^{\text {th }}$ International Conference on Mushroom Biology and Mushroom Products. 20-23 February, Cuernavaca, Mexico. 